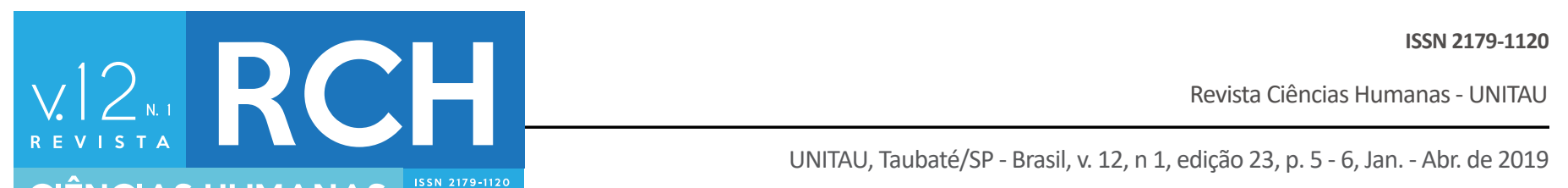

\title{
Estado, Sujeito e um olhar para a educação e o ensino
}

\section{EDITORIAL}

\author{
Alexandra Magna Rodrigues \\ Ana Maria Gimenes Corrêa Calil \\ Edna Maria Querido de Oliveira Chamon \\ Suzana Lopes Salgado Ribeiro
}

Este é um número comemorativo. A Revista de Ciências Humanas da Universidade de Taubaté - Unitau tem realizado nos últimos anos grandes conquistas. Na última avaliação da Capes fomos avaliados como B2 no Qualis interdisciplinar - área de nosso mestrado em Desenvolvimento Humano. Agora temos também o "Identificador de Objeto Digital" - DOI - nos artigos que publicamos, e que é responsável por tornar esses arquivos permanentes na internet. De certa forma, para comemorar esses bons ventos, intensificaremos o fluxo de nossas publicações, que se tornará quadrimestral, de modo que este é um primeiro volume deste ano de 2019 , e será composto por nove artigos.

Este número da revista se dedica a pensar nossa sociedade, mas com foco nos sujeitos, em seus processos formativos dentro e fora da escola. Entendemos, assim, que neste número a Revista Ciências Humanas, dá passo importante na direção do realinhamento de seu escopo, que se orienta tanto para as reflexões da interdisciplinaridade, quanto para os diálogos sobre educação e ensino. Isto, pois, compreendemos tais áreas como complementares em seus saberes e fazeres.

Dessa maneira, o primeiro artigo destaca "O papel do Estado na provisão do cuidado: entre a cobertura social e a 'crise do cuidado'" apontando as relações necessárias estabelecidas pelo Estado, de maneira a refletir sobre responsabilidades que vão para além do âmbito individual. Como contraponto, a constituição do próprio sujeito é tema de reflexão do segundo artigo apresentado que se intitula "Considerações acerca do processo de constituição da noção de sujeito".

Como forma de concretizar a discussão entre políticas públicas e constituição dos sujeitos algumas pesquisas apontam caminhos de como diferentes pessoas em diferentes momentos de suas vidas compreendem seus processos formativos em áreas distintas de formação. Estes são temas trabalhados nos artigos intitulados "Representações sociais do trabalho para menor aprendiz", "Visão de alunos e professores sobre melhorias na educação: pesquisa de campo em escolas públicas municipais de uma cidade sul mineira" e "Prevalência de sintomas depressivos em estudantes de Psicologia". 
A educação é pano de fundo das preocupações de muitos dos artigos deste número. Mas, num olhar mais de perto, é possível ver um outro bloco de discussão relacionado ao ensino, que ganha centralidade nas análises propostas pelos artigos "Educação musical: uma trilha pautada no contexto de época", "Avaliação da metodologia Theoprax para a formação profissionalizante no Senai-Bahia", "Planejamento da ação didática na educação especial: compreensões necessárias na elaboração do plano de AEE" e "Sociologia da Educação no Brasil: contextos e convergências".

Assim, os autores desta edição trazem reflexões científicas importantes para a compreensão das relações entre sujeito e sociedade no mundo contemporâneo, centrado no campo das Ciências Humanas, mas estabelecendo diálogos interdisciplinares. Desta maneira, mais uma vez, compreendemos que nossa revista contribui para o cenário das discussões da interdisciplinaridade e da formação e da educação. 